CZASOPISMO INŻYNIERII LACDOWEJ, ŚRODOWISKA I ARCHITEKTURY JOURNAL OF CIVIL ENGINEERING, ENVIRONMENT AND ARCHITECTURE

JCEEA, t. XXXII, z. 62 (3/1/15), lipiec-wrzesień 2015, s. 61-74

\author{
Michał CISZEWSKI ${ }^{1}$ \\ Tomasz BURATOWSKI ${ }^{2}$ \\ Tadeusz UHL ${ }^{3}$ \\ Mariusz GIERGIEL ${ }^{4}$ \\ Piotr MAŁKA ${ }^{5}$
}

\title{
MODELOWANIE I TESTY MOBILNEGO ROBOTA GĄSIENICOWEGO DO INSPEKCJI ORAZ OCZYSZCZANIA ZBIORNIKÓW Z WODĄ PITNĄ
}

\begin{abstract}
$\mathrm{W}$ artykule przedstawiono modelowanie oraz projekt i testy mobilnego robota gąsienicowego do inspekcji oraz oczyszczania zbiorników z wodą pitną. Urządzenia tego typu używane są do zwiększenia efektywności czynności związanych z utrzymaniem stanu technicznego obiektów przemysłowych. Przegląd dostępnych rozwiązań doprowadził do wyboru napędu gąsienicowego, zapewniającego najlepszą trakcję podczas poruszania się po dnie zbiorników. Zaprezentowany proces projektowania układów mechanicznych oraz elektronicznych zawiera opis doboru parametrów geometrycznych, materiałów konstrukcyjnych oraz tworzenie modelu trójwymiarowego robota. Zostały opisane różne warianty zastosowana robota w tym inspekcja przy użyciu sonaru 3D oraz transport robota pływającego. Wykonany zostały również analizy przy użyciu Metody Elementów Skończonych (MES), konieczne do poprawnego zaprojektowania konstrukcji. Analizy obejmowały badania wytrzymałościowe obudowy układu sterowania w warunkach zanurzenia w cieczy oraz analizę modalną ramy nierdzewnej robota. W artykule przestawiono model matematyczny dynamiki robota opisany równaniami Maggi'ego. Model pozwala na sterowanie silnikami w celu osiągnięcia zadanej pozycji i orientacji robota $\mathrm{w}$ przestrzeni roboczej. Na podstawie modelu matematycznego sporządzono symulacje ruchu robota, które zostały zweryfikowane laboratoryjnie. W symulacjach przedstawiono prędkości i momenty napędowe silników robota podczas ruchu po powierzchni płaskiej i po wniesieniu. W artykule przedstawiono
\end{abstract}

1 Autor do korespondencji/corresponding author: Michał Ciszewski, AGH Akademia GórniczoHutnicza w Krakowie, Al. Mickiewicza 30, 30-059 Kraków, tel. 12 6173116, mcisz@agh.edu.pl

2 Tomasz Buratowski, AGH Akademia Górniczo-Hutnicza w Krakowie, Al. Mickiewicza 30, 30059 Kraków, tel. 12 6173631, tburatow@agh.edu.pl

${ }^{3}$ Tadeusz Uhl, KRIM, AGH Akademia Górniczo-Hutnicza w Krakowie, Al. Mickiewicza 30, 30059 Kraków, tel. 12 6173116, tuhl@agh.edu.pl

${ }^{4}$ Mariusz Giergiel, AGH Akademia Górniczo-Hutnicza w Krakowie, Al. Mickiewicza 30, 30-059 Kraków, tel. 12 6173675, giergiel@agh.edu.pl

5 Piotr Małka, AGH Akademia Górniczo-Hutnicza w Krakowie, Al. Mickiewicza 30, 30-059 Kraków, tel. 12 6173116, piotr.malka@agh.edu.pl 
również prototyp robota, który sprawdzono pod względem wymaganej funkcjonalności w środowisku pracy.

Słowa kluczowe: modelowanie, model dynamiki, mobilny robot, woda pitna, inspekcja zbiorników, robot gąsienicowy, testy prototypu, analizy MES

\section{Wprowadzenie}

Przeglądając dostępną literaturę na temat robotyki zauważyć można, iż coraz częściej podejmowane są tematy dotyczące wykorzystania robotyki w przemyśle działającym w obszarze prac pod wodą, między innymi w przemyśle okrętowym, w pracach związanych z uzdatnianiem wody oraz inspekcji przewodów kanalizacyjnych. Tego typu roboty wykorzystywane są do diagnostyki, konserwacji oraz serwisowania urządzeń technicznych. Głównymi zaletami tego typu robotów jest: mobilność, manewrowość, współdziałanie z człowiekiem oraz otoczeniem w sposób autonomiczny.

\section{Konstrukcja robota inspekcyjnego}

\subsection{Układ napędowy}

Konstrukcja robotów inspekcyjnych przeznaczonych do poruszania się w zmiennych warunkach musi być dostosowana w sposób zapewniający jak największą mobilność jednostki. W oparciu o przegląd dostępnych rozwiązań, zdecydowano się zastosować napędy gąsienicowe Inuktun Minitrac [3]. Główną zaletą napędu gąsienicowego w stosunku do napędu kołowego jest lepsza skuteczność w pokonywaniu nierówności oraz lepsza trakcja, uzyskiwana przez większą powierzchnię kontaktu gąsienicy z podłożem [6]. W tego typu konstrukcjach nie stosuje się aktywnego zawieszenia, gdyż wprowadza ono dodatkowe komplikacje podczas zapewnienia szczelności urządzenia w warunkach podwodnych. Moduły napędowe zastosowane w robocie zawierają zamknięte w szczelnej obudowie silnik z przekładnią, napędzające gumową gąsienicę. Elementy napędowe mają atest szczelności do $30 \mathrm{~m}$ głębokości.

Głównym elementem konstrukcji robota jest rama wykonana ze spawanych segmentów rur oraz złączek nierdzewnych. Podczas projektowania ramy została przewidziana możliwość zmiany konfiguracji przestrzennej elementów w przypadku potrzeby modyfikacji układu nośnego robota. W tym celu zastosowano połączenia skręcane części elementów. Konstrukcja ramy robota została przystosowana do instalacji dodatkowych komponentów w zależności od zastosowania robota. Montaż kamery CCTV wraz z oświetleniem można przeprowadzić za pomocą obejm mocowanych do segmentów ramy lub płyty umieszczonej z przodu robota, przeznaczonej do montażu pompy lub sonaru. 


\subsection{Układy elektroniczne}

W wewnętrznej części ramy robota znajduje się układ elektroniczny odpowiedzialny za sterowanie podzespołami napędowymi oraz oprzyrządowaniem robota. Został on umieszczony w uszczelnianej obudowie aluminiowej pełniącej również funkcję wymiennika ciepła, przedstawionej na Rys. 1.

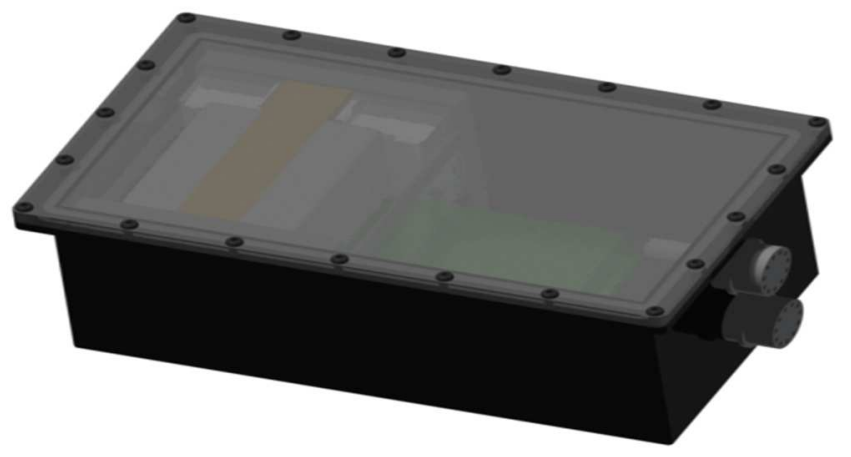

Rys. 1. Obudowa wodoszczelna na układy elektroniczne sterujące

Fig. 1. Waterproof case for control system electronics

Kabel biegnący od operatora robota podłączany jest do obudowy za pomocą złącza wodoszczelnego. Do zasilania urządzeń podwodnych stosuje się kable wysokonapięciowe, o jak najmniejszej średnicy, aby zapewnić dostateczną ilość energii przy zredukowanej grubości przewodów. Elastyczność okablowania jest niezbędna do prawidłowego ruchu robota podwodnego. W robocie zastosowano kabel przystosowany do pracy pod napięciem $600 \mathrm{~V}$, a robot zasilany jest prądem stałym. Aby umożliwić pracę urządzeń znajdujących się na wyposażeniu robota przewidziano zastosowanie przetwornicy podającej trzy różne napięcia, w tym 48 VDC do zasilania gąsienic i sterownika PLC oraz 230 V AC do zasilania pompy.

\subsection{Zastosowanie}

Do zastosowania robota do oczyszczania zbiorników z wodą pitną, wyposażono robota $w$ pompę zatapialną do wody zanieczyszczonej o wydajności do $10,8 \mathrm{~m}^{3} \cdot \mathrm{h}^{-1}$ i nominalnej wysokości podnoszenia $10,3 \mathrm{~m}$. Robot przemieszczając się po dnie zbiornika ma możliwość wykonania o wiele dokładniejszego czyszczenia bez potrzeby opróżniania zbiornika w stosunku do metody w której pompa jest wprowadzana w jedno miejsce. Dodatkowo, zamontowany do otworu ssawnego zgarniacz osadu ze szczotką pozwala na dokładniejsze zebranie grubszej frakcji zanieczyszczeń z dna zbiornika. Aby odprowadzić zanieczyszczoną wodę z dna zbiornika na zewnątrz, wykorzystany został przewód podłączony do pompy zamontowanej na robocie. Montaż pompy na robocie przeprowadzony został za pomocą rozszerzanej wraz z rozstawem gąsienic płyty montażowej. 
Środek pompy z wlotem umieszczono w osi centralnej robota w celu uproszczenia nawigacji, koniecznej do wyczyszczenia całego dna zbiornika. Model robota z zamontowaną pompą przedstawiono na Rys. 2. a).

Do przeprowadzenia zadań inspekcyjnych w zbiornikach z cieczą stosowany jest sonar Tritech Eclipse, który posiada możliwość tworzenia trójwymiarowego obrazu przestrzeni podwodnych [8]. Montaż sonaru do ramy robota, zamiennie z pompą umożliwia regulowana płyta montażowa. Dodatkowo przewidziano regulację kąta nachylenia sonaru względem podłoża w celu zmiany skanowanego obszaru, gdyż pionowy kąt promienia sonaru wynosi $\pm 22^{\circ}$. Do otrzymania dokładnej regulacji kątowej zastosowano uchwyt kątowy Thorlabs AP/180M, za pomocą którego można otrzymać pozycje kątowe sonaru będące wielokrotnością $15^{\circ}$ [7]. Na Rys. 2 b) pokazano model robota z zamontowanym sonarem w pozycji pionowej, stosowanej do pomiaru obszaru z przodu robota. Sonar Tritech Eclipse wyposażony jest fabrycznie w dedykowany kabel, dostosowany do parametrów urządzenia, który musi być prowadzony osobno, wzdłuż kabla zasilająco-sterującego robota.

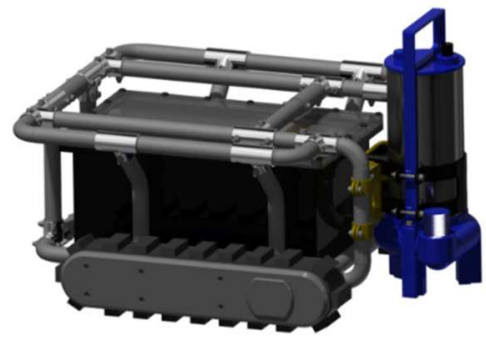

a)

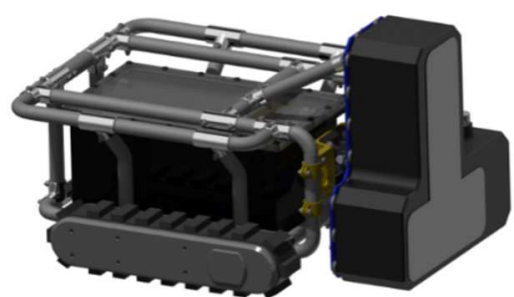

b)

Rys. 2. Model CAD robota gąsienicowego: a) z zamontowaną pompą, b) z zamontowanym sonarem 3D

Fig. 2. CAD model of the tracked robot: a) with a suction pump, b) with a 3D sonar

\subsection{Integracja $\mathrm{z}$ robotem pływającym}

Mobilny robot gąsienicowy jest również przystosowany do transportu pływającego robota inspekcyjnego, mającego na celu dokładną ocenę stanu technicznego ścian zbiorników za pomocą systemu wizyjnego opartego na trzech kamerach, czterech dalmierzach laserowych, oraz innych czujnikach w zależności od zapotrzebowania. Na górnej części ramy robota gąsienicowego zamieszczono prowadnice, pełniące funkcję stacji dokującej robota pływającego. Dla zapewnienia trwałego połączenia zastosowane zostaną zamki elektromagnetyczne. Podczas przemieszczania się po zbiorniku robot pływający będzie zadokowany na robocie gąsienicowym. Po oddaleniu się robota pływającego, robot gąsienicowy będzie utrzymywał niezmienną pozycję bazową, mającą ułatwić późniejszy powrót i dokowanie. Na Rys. 2 przedstawiono robota pływającego zadokowanego na robocie gąsienicowym. W górnej części robota pływającego 
umiejscowiona jest kamera wysokiej rozdzielczości z opcją obrotu w dwóch osiach oraz oddalania. Pozwoli ona na dokładne wykonanie inspekcji wizyjnej bez potrzeby nadmiernej zmiany pozycji robota. Na Rys. 2b) możemy zauważyć pędniki poziome robota, jak i umieszczony w osi centralnej pędnik pionowy.

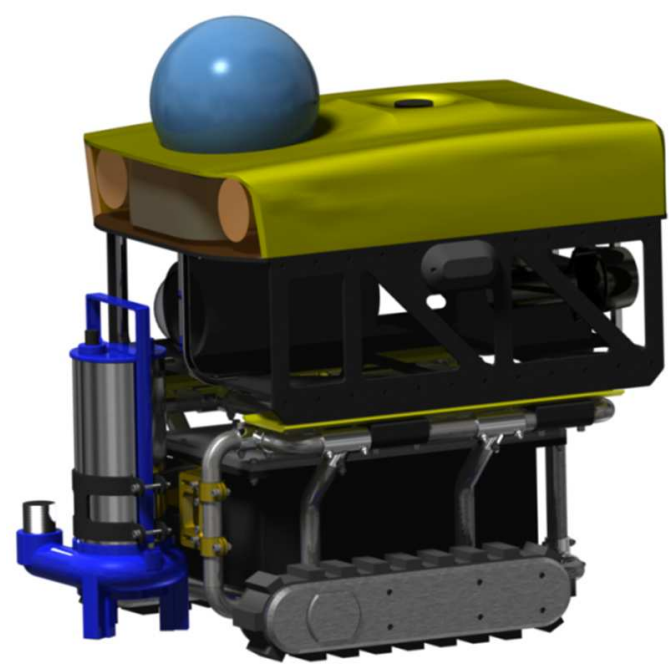

a)

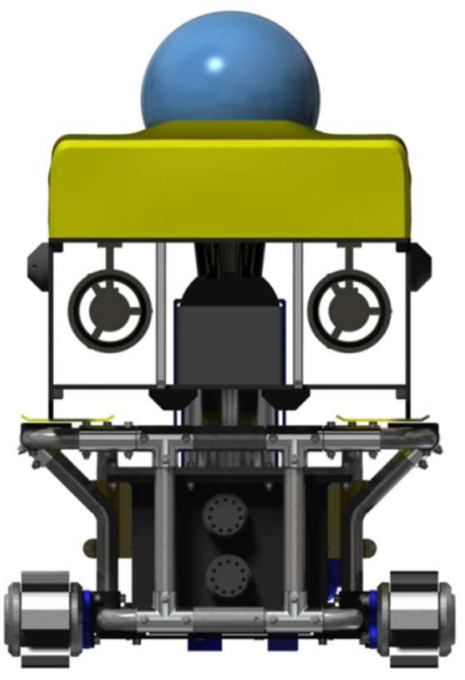

b)

Rys. 3. Transport zadokowanego robota pływającego: a) widok ogólny, b) widok od tyłu

Fig. 3. Transport of a docked ROV: a) general view, b) back view

\section{Analizy MES podzespołów robota}

\subsection{Analiza modalna ramy robota}

Do przeprowadzenia analizy modalnej ramy robota wykorzystane zostały środowiska ANSYS 14.0 oraz Autodesk Inventor 2013 Professional. Przygotowany uprzednio model w środowisku Autodesk Inventor został zaimportowany do środowiska ANSYS 14.0 Workbench oraz do zintegrowanego z programem do modelowania Autodesk Inventor środowiska Stress Analysis [4].

Celem wykorzystania różnych środowisk symulacyjnych była weryfikacja obliczeniowa. Do symulacji zostały przyjęte parametry przedstawione w Tab. 1 .

W obydwóch przypadkach wykorzystano elementy skończone tego samego typu - czworościany o analogicznych parametrach.

W programie ANSYS 14.0 zastosowano typ szybki przejścia między elementami, dający możliwość zagęszczania siatki w obszarach tego wymagających bez zbytniej komplikacji modelu [5]. 
Analizę ograniczono do identyfikacji 12 częstotliwości drgań własnych, a zakres obliczeń przyjęty został od 0.1 do $2000 \mathrm{~Hz}$. Przeprowadzono analizę nietłumioną bez narzucenia więzów kinematycznych oraz obciążeń.

W wyniku analizy uzyskano 12 częstotliwości własnych w zakresie od 184,4-625,6 Hz. Na Rys. 4 oraz Rys. 5 przedstawiono dwie pierwsze postaci drgań uzyskane w obydwu środowiskach symulacyjnych dla częstotliwości odpowiednio $184,72 \mathrm{~Hz}$ i $184,40 \mathrm{~Hz}$ oraz $204,01 \mathrm{~Hz}$ i $205,77 \mathrm{~Hz}$.

Tabela 1. Model MES - parametry symulacji

Table 1. Finite Element Model - parameters of simulation

\begin{tabular}{|c|c|c|}
\hline Parametr & $\begin{array}{c}\text { ANSYS } \\
14.0\end{array}$ & $\begin{array}{c}\text { Autodesk Inventor } \\
\text { Professional } 2013\end{array}$ \\
\hline Materiał & \multicolumn{2}{|c|}{ stal nierdzewna } \\
\hline Masa & \multicolumn{2}{|c|}{$8.25 \mathrm{~kg}$} \\
\hline Liczba elementów siatki & 89976 & 54869 \\
\hline Elementy zakrzywione/ typ przejścia & tak/ szybkie & tak/kąt maks. $60^{\circ}$ \\
\hline Typ elementów & \multicolumn{2}{|c|}{ czworościany } \\
\hline Zakres częstotliwości & \multicolumn{2}{|c|}{$0.1-2000 \mathrm{~Hz}$} \\
\hline Ilość poszukiwanych częstości własnych & \multicolumn{2}{|c|}{12} \\
\hline Typ analizy & \multicolumn{2}{|c|}{ nietłumiona } \\
\hline Więzy kinematyczne & \multicolumn{2}{|c|}{ swobodne } \\
\hline
\end{tabular}

Jak można zauważyć, postaci drgań, choć są przesunięte fazowo na przedstawionych rysunkach, pokrywają się. Analogiczną sytuację zaobserwowano przy porównaniu kolejnych postaci drgań.

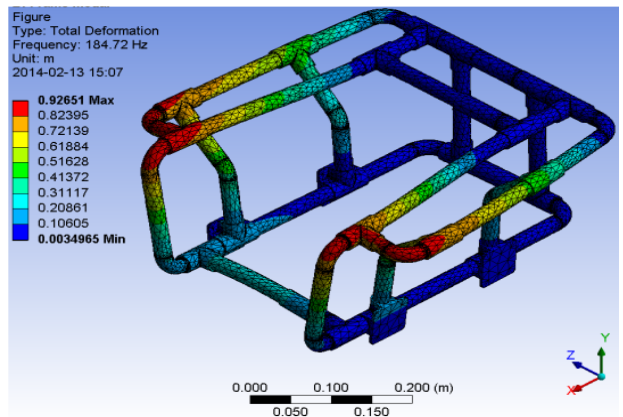

a)

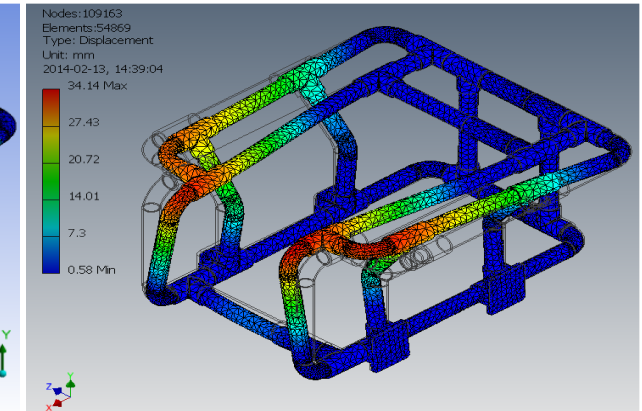

b)

Rys. 4. Postaci drgań uzyskane dla pierwszej częstotliwości drgań własnych w ANSYS 14.0 (a) oraz Autodesk Inventor 2013 Professional (b)

Fig. 4. Mode shapes obtained from ANSYS 14.0 (a) and Autodesk Inventor 2013 Professional (b) for the first natural frequency

Najniższe częstotliwości uzyskane przy pomocy analizy modalnej wynoszą odpowiednio 184,72 Hz oraz 184,40 Hz. Porównując je z częstotliwością gene- 
rowaną przez kontakt szponów gąsienic z podłożem, która przy maksymalnej prędkości gąsienic wynosi $4 \mathrm{~Hz}$, możemy zauważyć, że wymuszenie ma o wiele niższą wartość niż częstotliwość własna ramy. Gdy dołączymy do ramy robota napędy gąsienicowe, obudowę z układami elektronicznymi oraz oprzyrządowanie inspekcyjne, rama zostanie jeszcze usztywniona, co dodatkowo podwyższy częstotliwość drgań własnych.

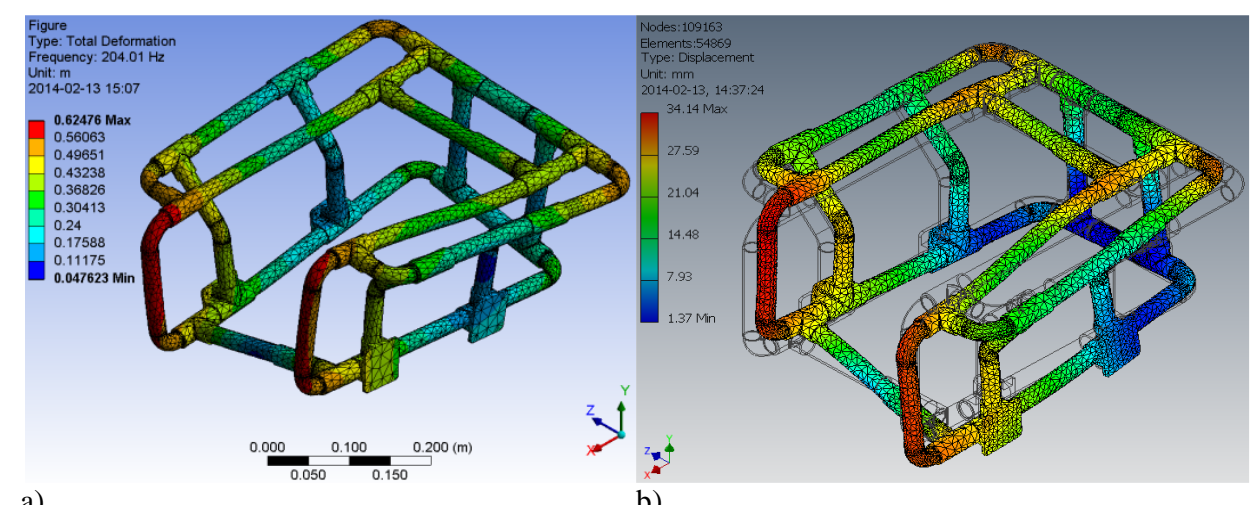

a)

b)

Rys. 5. Postaci drgań uzyskane dla pierwszej częstotliwości drgań własnych w ANSYS 14.0 (a) oraz Autodesk Inventor 2013 Professional (b)

Fig. 5. Mode shapes obtained from ANSYS 14.0 (a) and Autodesk Inventor 2013 Professional (b) for the second natural frequency

Porównanie wyników analizy obydwu środowisk symulacyjnych pozwoliło stwierdzić, że różnice w wynikach nie przekraczają $2.2 \%$, a w większości przypadków wynoszą poniżej 1\%, pomimo drobnych różnic w strukturze siatki elementów skończonych, co potwierdza poprawność przeprowadzonej analizy w obydwu środowiskach.

\subsection{Analizy wytrzymałościowe obudowy}

W celu zapewnienia poprawności funkcjonowania obudowy na układy sterowania robota przeprowadzono symulacje wytrzymałościowe aby dokonać doboru materiałów oraz elementów uszczelniających. Obudowy wodoszczelne zaprojektowane zostały w sposób umożliwiający szybki dostęp do podzespołów układu sterowania. Pokrywa górna zaprojektowana została z $12 \mathrm{~mm}$ grubości szkła akrylowego PMMA. Przezroczysta pokrywa pozwala na stały monitoring układów elektronicznych. Uszczelnienie czołowe z wykorzystaniem sznura oringowego daje możliwość użycia obudowy na dużej głębokości.

W procesie projektowania obudów wodoszczelnych zastosowano symulacje z wykorzystaniem Metody Elementów Skończonych. Część bazową obudowy wykonano ze spawanych płyt o grubości $5 \mathrm{~mm}$, z aluminium 2017A. Wymiary zostały dobrane na podstawie symulacji MES (Rys. 6). Odkształcenie pły- 
ty podczas działania ciśnienia $0.5 \mathrm{MPa}$ (na głębokości $50 \mathrm{~m}$ ) pokazano na Rys. 6 a) i wynosi ono $6.3 \mathrm{~mm}$ w środkowej części płyty. Warunek wytrzymałościowy materiału płyty jest spełniony. Ponieważ robot ma pracować na głębokości maksymalnie $30 \mathrm{~m}$, wynik jest zadowalający. Na Rys. 6 b) przedstawiono odkształcenie pozostałej części obudowy, które wynosi $0.95 \mathrm{~mm}$ przy tych samych warunkach obciążenia.

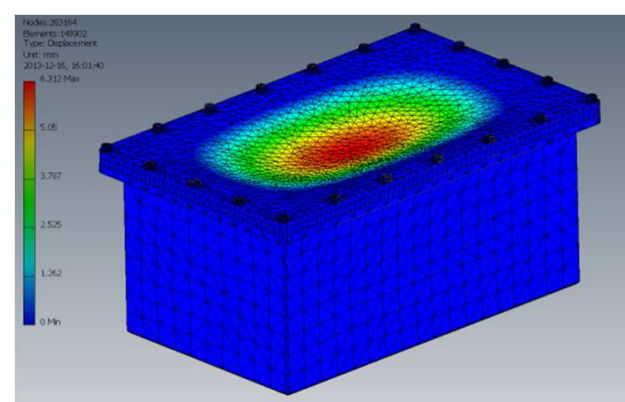

a)

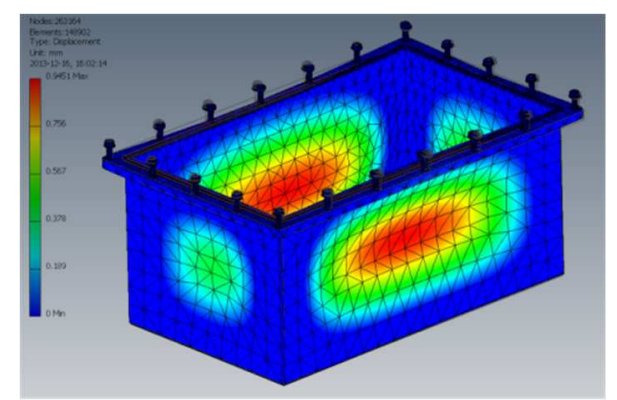

b)

Rys. 6. Analizy wytrzymałościowe MES obudowy wodoszczelnej: a) odkształcenie pokrywy, b) odkształcenie obudowy

Fig. 6. Finite Element Analyses of a waterproof case: a) deformation of the case lid, b) deformation of the case

Przeprowadzone symulacje wytrzymałościowe pokazują iż obudowy spełniają wymogi odnośnie warunków pracy przy zapewnieniu szczelności połączeń spawanych.

\section{Model matematyczny dynamiki robota}

$\mathrm{W}$ celu oszacowania pozycji i orientacji robota $\mathrm{w}$ przestrzeni na podstawie parametrów sterujących napędów gąsienicowych, koniecznym było stworzenie modelu matematycznego robota. Pierwszym krokiem był model kinematyki, przedstawiony $\mathrm{w}$ [2] dla wczesnej wersji prototypu. W modelu kinematyki zdefiniowano pozycję i orientację robota względem założonego układu współrzędnych. Następny krok obejmuje stworzenie modelu dynamiki robota z uwzględnieniem oddziaływania środowiska, w którym ma wykonywać określone zadania. Zdecydowano się na użycie równań Lagrange'a II rodzaju dla układu nieholonomicznego, którym jest robot, opisanych przez (1):

$$
\frac{\mathrm{d}}{\mathrm{dt}}\left(\frac{\partial \mathrm{E}}{\partial \dot{\mathrm{q}}}\right)^{\mathrm{T}}-\left(\frac{\partial \mathrm{E}}{\partial \mathrm{q}}\right)^{\mathrm{T}}=\mathrm{Q}+\mathrm{J}^{\mathrm{T}}(\mathrm{q}) \lambda
$$

gdzie: $q$ - wektor współrzędnych uogólnionych, 
$\dot{q}$ - wektor prędkości uogólnionych,

$L=E-V$ - potencjał kinetyczny Lagrange'a

$E=E(q, \dot{q})-$ energia kinetyczna układu,

$\mathrm{V}=V(q)-$ energia potencjalna układu,

$Q$ - wektor sił uogólnionych,

$J(q)$ - jakobian więzów nieholonomicznych,

$\lambda$ - wektor mnożników Lagrange'a

Należy przyjąć, że energia kinetyczna robota $E$ jest sumą energii poszczególnych jego elementów, zgodnie z wyrażeniem (2):

$$
\mathrm{E}=\mathrm{E}_{\mathrm{R}}+\mathrm{E}_{\mathrm{M} 1}+\mathrm{E}_{\mathrm{M} 2}
$$

gdzie: $E_{R}$ - energia kinetyczna ramy

$\mathrm{E}_{\mathrm{M} 1}$ - energia kinetyczna lewego modułu napędowego robota,

$\mathrm{E}_{\mathrm{M} 2}$ - energia kinetyczna prawego modułu napędowego robota.

Po wykonaniu przekształceń z uwzględnieniem więzów nieholonomicznych oraz zsumowaniu sił bezwładności działających na robota otrzymujemy równanie (3) dla modułów napędowych.

$$
\begin{aligned}
& \mathrm{E}_{\mathrm{M} 1}=\frac{1}{2} \mathrm{~m}\left(\left(\dot{\mathrm{x}}_{\mathrm{C}}-\dot{\beta} \mathrm{H} \sin \beta\right)^{2}+\left(\dot{\mathrm{y}}_{\mathrm{C}}-\dot{\beta} \mathrm{H} \cos \beta\right)^{2}+\dot{\mathrm{z}}_{\mathrm{C}}^{2}\right)+\frac{1}{2} \mathrm{I}_{\mathrm{x}} \dot{\alpha}_{1}^{2}+\frac{1}{2} \mathrm{I}_{\mathrm{z}} \dot{\beta}^{2} \\
& \mathrm{E}_{\mathrm{M} 2}=\frac{1}{2} \mathrm{~m}\left(\left(\dot{\mathrm{x}}_{\mathrm{C}}+\dot{\beta} \mathrm{H} \sin \beta\right)^{2}+\left(\dot{\mathrm{y}}_{\mathrm{C}}+\dot{\beta} \mathrm{H} \cos \beta\right)^{2}+\dot{\mathrm{z}}_{\mathrm{C}}^{2}\right)+\frac{1}{2} \mathrm{I}_{\mathrm{x}} \dot{\alpha}_{2}^{2}+\frac{1}{2} \mathrm{I}_{\mathrm{z}} \dot{\beta}^{2}
\end{aligned}
$$

Po zsumowaniu energii kinetycznej modułów napędowych robota oraz energii kinetycznej ramy otrzymano całkowitą energię kinetyczną (4):

$$
\begin{aligned}
\mathrm{E}= & \frac{1}{2} \mathrm{~m}_{\mathrm{R}}\left(\dot{\mathrm{x}}_{\mathrm{C}}{ }^{2}+\dot{\mathrm{y}}_{\mathrm{C}}{ }^{2}+\dot{\mathrm{z}}_{\mathrm{C}}^{2}\right)+\frac{1}{2} \mathrm{I}_{\mathrm{R}} \dot{\beta}^{2}+\frac{1}{2} \mathrm{~m}\left(\left(\dot{\mathrm{x}}_{\mathrm{c}}-\dot{\beta} \mathrm{H} \sin \beta\right)^{2}+\left(\dot{\mathrm{y}}_{\mathrm{C}}-\dot{\beta} \mathrm{H} \cos \beta\right)^{2}+\dot{\mathrm{z}}_{\mathrm{C}}^{2}\right)+ \\
& +\frac{1}{2} \mathrm{I}_{\mathrm{x}} \dot{\alpha}_{1}^{2}+\mathrm{I}_{\mathrm{z}} \dot{\beta}^{2}+\frac{1}{2} \mathrm{~m}\left(\left(\dot{\mathrm{x}}_{\mathrm{C}}+\dot{\beta} \mathrm{H} \sin \beta\right)^{2}+\left(\dot{\mathrm{y}}_{\mathrm{C}}+\dot{\beta} \mathrm{H} \cos \beta\right)^{2}+\dot{\mathrm{z}}_{\mathrm{C}}^{2}\right)+\frac{1}{2} \mathrm{I}_{\mathrm{x}} \dot{\alpha}_{2}^{2}
\end{aligned}
$$

gdzie: $\mathrm{r}$ - promień kół napędowych gąsienice,

$\mathrm{H}$ - odległość pomiędzy osiami gąsienic,

$\mathrm{P}_{\mathrm{u}}$ - siła uciągu,

$\mathrm{m}$ - masa modułu gąsienicowego, $\mathrm{m}_{\mathrm{R}}$ - masa ramy,

$\mathrm{I}_{\mathrm{R}}, \mathrm{I}_{\mathrm{z}}, \mathrm{I}_{\mathrm{x}}-$ masowe momenty bezwładności,

$\beta$ - kąt obrotu ramy robota,

$\gamma$ - kąt wzniesienia

$\ddot{\alpha}_{1}$ - przyspieszenie kątowe koła napędowego gąsienicy 1 ,

$\ddot{\alpha}_{2}$ - przyspieszenie kątowe koła napędowego gąsienicy 2 , 
$\dot{\alpha}_{1}$ - prędkość kątowa koła napędowego gąsienicy 1,

$\dot{\alpha}_{2}$ - prędkość kątowa koła napędowego gąsienicy 2,

$\mathrm{s}_{1}$ - poślizg gąsienicy 1 ,

$\mathrm{s}_{2}-$ poślizg gąsienicy 2 .

Energia kinetyczna robota została użyta w równaniach Lagrange'a II rodzaju. Na podstawie przekształceń i po odprzężeniu mnożników Lagrange'a, uzyskano równania dynamiczne ruchu robota, postępując analogicznie do przekształceń przedstawionych w [1]. Są to równania Maggi'ego, pozwalające na sterowanie silnikami robota $\mathrm{w}$ celu osiągnięcia zadanej pozycji i orientacji $(5),(6)$.

$$
\begin{aligned}
& \left(\begin{array}{l}
\frac{\mathrm{r}}{2}\left[\ddot{\alpha}_{1}\left(1-\mathrm{s}_{1}\right)+\ddot{\alpha}_{2}\left(1-\mathrm{s}_{2}\right)\right] \sin \beta+ \\
+\frac{\mathrm{r}}{2}\left[\dot{\alpha}_{1}\left(1-\mathrm{s}_{1}\right)+\dot{\alpha}_{2}\left(1-\mathrm{s}_{2}\right)\right] \frac{\dot{\mathrm{\alpha}}_{2}\left(1-\mathrm{s}_{2}\right)-\dot{\alpha}_{1}\left(1-\mathrm{s}_{1}\right)}{\mathrm{H}} \cos \beta
\end{array}\right)\left(\mathrm{m}_{\mathrm{R}}+2 \mathrm{~m}\right) \frac{1}{2} \mathrm{r}\left(1-\mathrm{s}_{1}\right) \sin \beta+ \\
& +\left(\begin{array}{l}
\frac{\mathrm{r}}{2}\left[\ddot{\alpha}_{1}\left(1-\mathrm{s}_{1}\right)+\ddot{\alpha}_{2}\left(1-\mathrm{s}_{2}\right)\right] \cos \beta \cos \gamma- \\
+\frac{\mathrm{r}}{2}\left[\dot{\alpha}_{1}\left(1-\mathrm{s}_{1}\right)+\dot{\alpha}_{2}\left(1-\mathrm{s}_{2}\right)\right] \frac{\mathrm{r} \dot{\alpha}_{2}\left(1-\mathrm{s}_{2}\right)-\dot{\alpha}_{1}\left(1-\mathrm{s}_{1}\right)}{\mathrm{H}} \sin \beta \cos \gamma
\end{array}\right)\left(\mathrm{m}_{\mathrm{R}}+2 \mathrm{~m}\right) \frac{1}{2} \mathrm{r}\left(1-\mathrm{s}_{1}\right) \cos \beta \cos \gamma+ \\
& +\left(\frac{\mathrm{r}}{2}\left[\ddot{\alpha}_{1}\left(1-\mathrm{s}_{1}\right)+\ddot{\alpha}_{2}\left(1-\mathrm{s}_{2}\right)\right] \sin \gamma\right)\left(\mathrm{m}_{\mathrm{R}}+2 \mathrm{~m}\right) \frac{1}{2} \mathrm{r}\left(1-\mathrm{s}_{1}\right) \sin \gamma- \\
& +\left(\frac{\ddot{\alpha}_{2}\left(1-s_{2}\right)-r \ddot{\alpha}_{1}\left(1-s_{1}\right)}{H}\right)\left(I_{R}+2 I_{z}+2 m H^{2}\right) \frac{r\left(1-s_{1}\right)}{H}+I_{x} \ddot{\alpha}_{1} \\
& =\mathrm{M}_{\mathrm{n} 1}+\left(-0,5 \mathrm{P}_{\mathrm{u}}-0,5 \mathrm{~F}_{\mathrm{D}}-0,5 \mathrm{G} \sin \gamma+0,5 \mathrm{~F}_{\mathrm{w}} \sin \gamma-0,5 \mathrm{~W}_{\mathrm{t} 1}\right) \mathrm{r}\left(1-\mathrm{s}_{1}\right)+\mathrm{M}_{\mathrm{p}} \frac{\mathrm{r}\left(1-\mathrm{s}_{1}\right)}{\mathrm{H}} \\
& \left(\begin{array}{l}
\frac{\mathrm{r}}{2}\left[\ddot{\alpha}_{1}\left(1-\mathrm{s}_{1}\right)+\ddot{\alpha}_{2}\left(1-\mathrm{s}_{2}\right)\right] \sin \beta+ \\
+\frac{\mathrm{r}}{2}\left[\dot{\alpha}_{1}\left(1-\mathrm{s}_{1}\right)+\dot{\alpha}_{2}\left(1-\mathrm{s}_{2}\right)\right] \frac{\mathrm{r} \dot{\alpha}_{2}\left(1-\mathrm{s}_{2}\right)-\dot{\alpha}_{1}\left(1-\mathrm{s}_{1}\right)}{\mathrm{H}} \cos \beta
\end{array}\right)\left(\mathrm{m}_{\mathrm{R}}+2 \mathrm{~m}\right) \frac{1}{2} \mathrm{r}\left(1-\mathrm{s}_{2}\right) \sin \beta+ \\
& +\left(\begin{array}{l}
\frac{\mathrm{r}}{2}\left[\ddot{\alpha}_{1}\left(1-\mathrm{s}_{1}\right)+\ddot{\alpha}_{2}\left(1-\mathrm{s}_{2}\right)\right] \cos \beta \cos \gamma- \\
+\frac{\mathrm{r}}{2}\left[\dot{\alpha}_{1}\left(1-\mathrm{s}_{1}\right)+\dot{\alpha}_{2}\left(1-\mathrm{s}_{2}\right)\right] \frac{\mathrm{r} \dot{\alpha}_{2}\left(1-\mathrm{s}_{2}\right)-\dot{\alpha}_{1}\left(1-\mathrm{s}_{1}\right)}{\mathrm{H}} \sin \beta \cos \gamma
\end{array}\right)\left(\mathrm{m}_{\mathrm{R}}+2 \mathrm{~m}\right) \frac{1}{2} \mathrm{r}\left(1-\mathrm{s}_{2}\right) \cos \beta \cos \gamma+ \\
& +\left(\frac{\mathrm{r}}{2}\left[\ddot{\alpha}_{1}\left(1-\mathrm{s}_{1}\right)+\ddot{\alpha}_{2}\left(1-\mathrm{s}_{2}\right)\right] \sin \gamma\right)\left(\mathrm{m}_{\mathrm{R}}+2 \mathrm{~m}\right) \frac{1}{2} \mathrm{r}\left(1-\mathrm{s}_{2}\right) \sin \gamma+ \\
& +\left(\frac{\mathrm{r} \ddot{\alpha}_{2}\left(1-\mathrm{s}_{2}\right)-\ddot{\alpha}_{1}\left(1-\mathrm{s}_{1}\right)}{\mathrm{H}}\right)\left(\mathrm{I}_{\mathrm{R}}+2 \mathrm{I}_{\mathrm{z}}+2 \mathrm{mH}^{2}\right) \frac{\mathrm{r}\left(1-\mathrm{s}_{2}\right)}{\mathrm{H}}+\mathrm{I}_{\mathrm{x}} \ddot{\alpha}_{2} \\
& =M_{n 2}+\left(-0,5 P_{u}-0,5 F_{D}-0,5 G \sin \gamma+0,5 F_{w} \sin \gamma-0,5 \mathrm{~W}_{\mathrm{t} 2}\right) r\left(1-\mathrm{s}_{2}\right)-\mathrm{M}_{\mathrm{p}} \frac{\mathrm{r}\left(1-\mathrm{s}_{2}\right)}{\mathrm{H}}
\end{aligned}
$$


Należy jednak nadmienić, że przy wystąpieniu poślizgu obydwóch gąsienic, którego wartość będzie zmieniać się w czasie, określona pozycja i orientacja robota będzie jedynie orientacyjna.

$\mathrm{Na}$ podstawie modelu matematycznego przeprowadzono symulacje przejazdu robota w środowisku wodnym.

\section{Testy laboratoryjne prototypu}

Na podstawie stworzonych modeli trójwymiarowych CAD został wykonany prototyp robota. Po podłączeniu układów elektronicznych oraz zasilania, gotowy prototyp został przetestowany oraz jego parametry ruchu zostały porównane $\mathrm{z}$ symulacją otrzymaną przy użyciu modelu matematycznego, opisującego równania dynamiki robota (5),(6).

Trajektorią przejazdu robota był odcinek powierzchni płaskiej przechodzący we wzniesienie o nachyleniu $15^{\circ}$, na którego końcu ponownie znajdowała się powierzchnia płaska.

Na Rys. 7 przedstawiono wykresy prędkości robota oraz momentów napędowych silników gąsienic, uzyskane z symulacji wykonanej w oprogramowaniu Matlab/Simulink oraz podczas testów laboratoryjnych na stanowisku o analogicznie zadanej trajektorii.

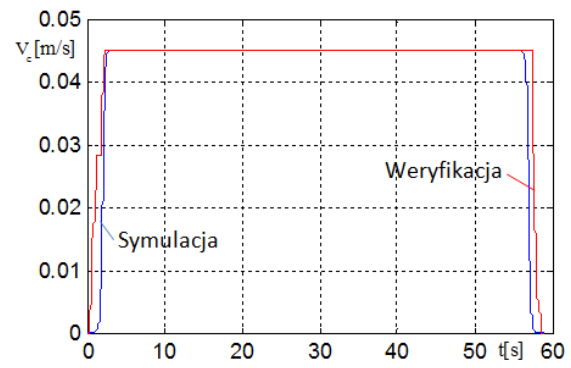

a)

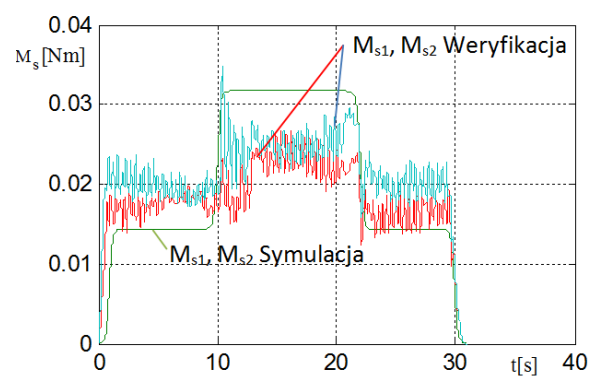

b)

Rys. 7. Symulacja oraz weryfikacja ruchu prototypu robota: a) prędkość, b) momenty napędowe silników gąsienic

Fig. 7. Simulation and verification of motion of the prototype: a) velocity, b) driving torque of track drive motors

W przypadku prędkości można zaobserwować analogię pomiędzy symulacją i weryfikacją laboratoryjną. Wykresy momentów pokazują natomiast, że podczas przejazdu po płaskiej powierzchni, większy moment konieczny jest do poruszania robotem. Zauważalne również są cykliczne zmiany wartości momentu spowodowane zmianą kontaktu ostróg gąsienic z podłożem. Przeprowadzone testy pozwoliły na dostosowanie parametrów modelu matematycznego. 


\section{Testy środowiskowe prototypu}

Po przeprowadzeniu testów laboratoryjnych prototypu robota, przystąpiono do testów środowiskowych, podczas których sprawdzone zostały poszczególne podzespoły w warunkach pracy. Na Rys. 8 przedstawiono prototyp robota podczas testów przejazdu po betonowym dnie zbiornika. Testy wykazały dużą skuteczność zastosowanych napędów gąsienicowych. Rys. 9 przedstawia prototyp robota przystosowany do oczyszczania dna zbiorników. Testy wykazały, że pompa wraz z zamontowanym zgarniaczem osadu posiada założoną funkcjonalność.

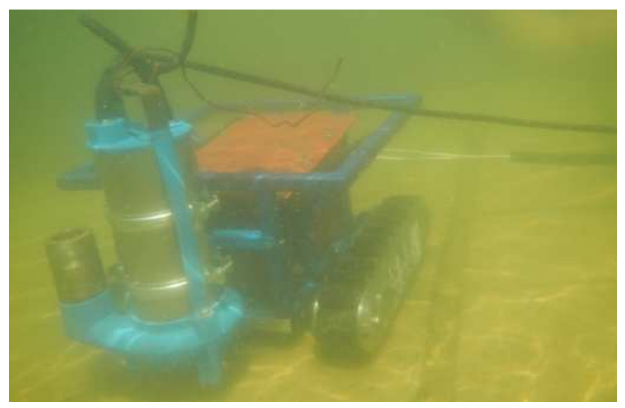

a)

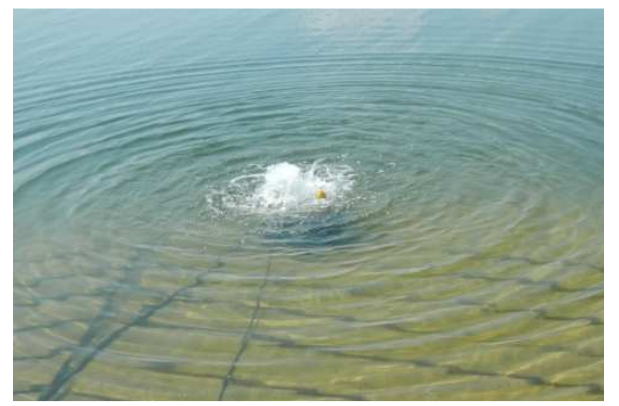

b)

Rys. 8. Prototyp robota podczas poruszania się po dnie zbiornika: a) test pracy gąsienic, b) test pracy pompy

Fig. 8. Robot prototype during motion underwater: a) test of track drive module, b) verification of pump performance

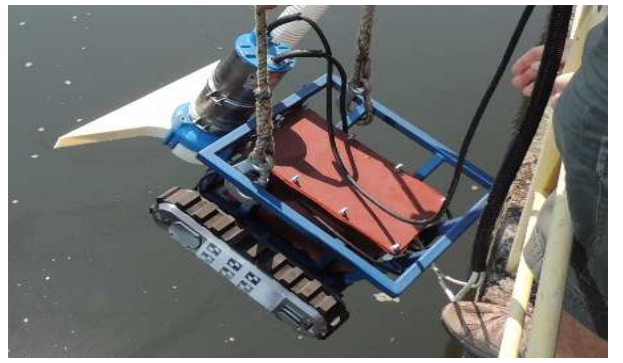

a)

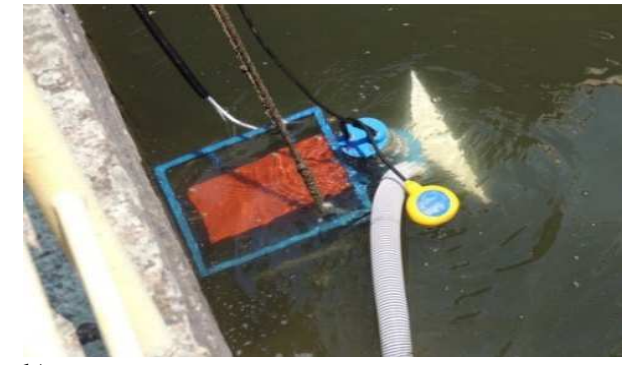

b)

Rys. 9. Prototyp robota podczas oczyszczania zbiornika wody pitnej z osadów: a) opuszczanie prototypu robota, b) zanurzony prototyp

Fig. 9. Robot prototype during cleaning operation of a water storage tank: a) lowering the robot, b) submerged prototype

Po przeprowadzeniu testów środowiskowych prototypu stwierdzono, że robot po niewielkich modyfikacjach może być zastosowany do konserwacji i inspekcji zbiorników z wodą pitną. 


\section{Wnioski i dalsze prace}

W pracy przedstawiony został robot do inspekcji i oczyszczania zbiorników $\mathrm{z}$ wodą pitną. Zastosowanie takiego urządzenia może ułatwić czynności konserwacyjne związane $\mathrm{z}$ oczyszczaniem i monitorowaniem stanu technicznego zbiorników, zmniejszyć czasy przestojów i przynieść korzyści ekonomiczne.

$\mathrm{W}$ artykule przedstawiono proces projektowy począwszy od modelu CAD, w którym uwzględnione zostały wszystkie podzespoły robota, włącznie z układami zasilania i sterowania. Stworzenie modelu CAD poprzedzone było analizą dostępnych rozwiązań w zakresie robotów przeznaczonych do pracy w warunkach wodnych.

Podczas procesu projektowego przeprowadzone zostały analizy modalne ramy robota, które pozwoliły potwierdzić poprawność rozwiązania konstrukcyjnego ze względu na możliwość wystąpienia niepożądanych drgań podczas pracy. Do analiz wykorzystano dwa środowiska symulacyjne, a uzyskane wyniki są zbieżne.

Na podstawie parametrów modelu CAD stworzony został model matematyczny robota, pozwalający na uzyskanie wymaganych parametrów układów napędowych w celu realizacji zadanej trajektorii. Weryfikacja symulacji wykonanej na podstawie przygotowanego modelu oraz pomiarów podczas przejazdów prototypu robota wykazała zbieżność założeń teoretycznych z praktyką. Badania funkcjonalności podzespołów robota w środowisku pracy dowiodły, iż zaproponowane rozwiązanie gotowe jest do rozpoczęcia pracy w założonych warunkach.

W ramach dalszych prac przewidziany jest rozwój systemu sterowania, który $\mathrm{w}$ chwili obecnej funkcjonuje w trybie teleoperatorskim. Doprecyzowanie modelu matematycznego zgodnie $\mathrm{z}$ wykonanymi testami prototypu umożliwi stworzenie uproszczonego planera trajektorii koniecznego do półautomatycznej inspekcji i oczyszczania zbiorników z cieczą. Dodatkowo przewidziany jest montaż uzupełniającej aparatury inspekcyjnej w zależności od zapotrzebowania.

\section{Literatura}

[1] Ciszewski M., Buratowski T., Giergiel M., Kurc K., Małka, P.: Virtual prototyping, design and analyses of an in-pipe inspection mobile robot. Journal of Theoretical and Applied Mechanics 52 No.2 (2014), 417-429.

[2] Giergiel M. et al: Kinematics of underwater inspection robot. Pomiary automatyka Robotyka, 2012, vol. 12, pp. 122-116.

[3] Inuktun Minitracs, http://www.inuktun.com/crawler-tracks/minitracs.html, [dostęp 12.03.2012].

[4] Jaskulski A.: Autodesk Inventor Professional. Fusion 2013PL/2013+, Metodyka projektowania, Wydawnictwo Naukowe PWN, 2012.

[5] Łaczek, S.: Przykłady analizy konstrukcji w systemie MES ANSYS-Workbench v.12.1, Wydawnictwo PK, Kraków, 2013.

[6] Małka P., Kurc K., Kohut P., Majkut K.: M. Giergiel, T. Buratowski. The project of tank inspection robot, Key Engineering Materials, 2012, vol. 518, s. 375-383. 
[7] Thorlabs: Adjustable mounting plate, http://www.thorlabs.de /thorproduct.cfm?partnumber=AP180/M, [dostęp 15.04.2014].

[8] Tritech: Eclipse multibeam sonar, http://www.tritech.co.uk/product/multibeamsonar-for-3d-model-view-of-sonar-imagery-eclipse, [dostęp 13.03.2014].

\section{MODELING AND TESTING OF A TRACKED MOBILE ROBOT FOR INSPECTION AND CLEANING OF WATER STORAGE TANKS}

\section{S u m m a r y}

This paper presents modeling, design and testing of a tracked mobile robot intended to cleaning and inspection of water tanks. This kind of devices is used to increase effectiveness of maintenance of industrial facilities. A market and literature research lead to selection of a track drive as the main motion unit due to good traction. The presented design process consists of design of mechanical components and electronics and creation of a 3D model. Different applications of the robot, including transport of a ROV robot and inspection tasks with the use of a 3D sonar were described. Finite Element Method analyses (FEM) were used to check strength of waterproof casing for power supply and electronics in environment simulating submersion. Additionally, modal analysis of the main frame of the robot was performed. A mathematical model of the robot that describes dynamics was presented with usage of Maggi equations. The model provides parameters required for the drives to control the robot's position and orientation. The mathematical model was used to create motion simulations of the robot that were verified experimentally in laboratory. The simulations and tests featured generation and measurement of velocities and driving torques of motors. The functionality of the prototype of the robot was tested in operating conditions.

Keywords: modeling, dynamic model, mobile robot, drinking water, tank inspection, tracked robot, prototype testing FEM analyses

Przestano do redakcji: $30.05 .2015 r$.

Przyjęto do druku:30.10.2015r.

DOI: $10.7862 / \mathrm{rb} .2015 .95$ 